\title{
PENGARUH KEPEMIMPINAN DAN KOMUNIKASI TERHADAP KINERJA KARYAWAN PT. BPJS KETENAGAKERJAAN KANTOR WILAYAH DKI JAKARTA
}

\author{
M. Irawan Noor *) \\ *) Dosen Program Studi Manajemen FE UNKRIS \\ Alamat: Kampus UNKRIS, Jatiwaringin Jakarta Timur \\ Email: iwandahlia58@gmail.com
}

\begin{abstract}
The purpose of this study was to determine the effect of leadership and communication on the performance of PT. DKI Jakarta Regional Office BPJS Employment. The research method used is descriptive quantitative method using a survey system. The population in this study were employees at PT. DKI Jakarta Regional Office BPJS, totaling 30 employees. Researchers took and used all populations to be sampled using the method of multiple linear regression analysis and simple. The results showed that 1). Together leadership and communication greatly affect the performance of employees at PT. DKI Jakarta Regional Office BPJS Employment, 2). That leadership influences employee performance at PT. DKI Jakarta Regional Office BPJS Employment. 3). The results showed that communication affects the performance of employees at PT. DKI Jakarta Regional Office BPJS Employment.
\end{abstract}

Keywords: Leadership, communication and employee performance

\section{PENDAHULUAN}

Sumber daya manusia merupakan komponen utama suatu perusahaan yang menjadi perencana dan pelaku aktif dalam setiap aktivitas perusahaan. Mereka mempunyai pikiran, perasaan, keinginan, status dan latar belakang pendidikan, usia, jenis kelamin yang heterogen yang dibawa kedalam suatu organisasi sehingga tidak seperti mesin, uang dan material, yang sifatnya pasif dan dapat dikuasai dan diatur sepenuhnya dalam mendukung tercapainya tujuan perusahaan. Sumber daya manusia baik yang menduduki posisi pimpinan maupun anggota merupakan faktor terpenting dalam setiap perusahaan pemerintah maupun swasta. Hal ini karena berhasil tidaknya suatu perusahaan sebagian besar dipengaruhi oleh faktor manusia selaku pelaksana pekerjaan.
Salah satu hal yang harus diperhatikan dalam pelaksanaan pekerjaan yaitu terwujudnya efektivitas kerja yang positif. Untuk mewujudkan efektivitas kerja yang positif tentunya bukan merupakan usaha yang mudah, karena dipengaruhi beberapa faktor diantaranya: lingkungan kerja, tata ruang kantor, suasana kerja, gaya kepemimpinan dan komunikasi baik internal maupun eksternal dan lain sebagainya.

Dalam suatu perusahaan, kepemimpinan berkaitan dengan pengarahan kepada karyawan untuk melakukan pekerjaan. Ini menjadi bagian penting dalam memahami perilaku kerja. Beberapa penelitian telah memperlihatkan bahwa tidak ada suatu cara terbaik untuk memimpin bawahan. Ini tergantung pada pemimpinnya, bawahan, dan situasi yang ada. 
Pemimpin yang baik pasti akan mendapatkan hasil pekerjaan lebih banyak dari bawahannya dengan sikap sebagai pemimpin yang baik. Untuk mengetahui sikap kepemimpinan yang sesuai, mereka tidak hanya melihat posisinya sebagai pemimpin yang menghendaki segalanya telah dilakukan, tetapi mereka harus pula bekerja dalam struktur yang ada secara efektif.

$$
\text { Menurut Rivai (2004), }
$$
menyatakan bahwa: Kepemimpinan adalah proses mempengaruhi atau memberi contoh kepada pengikutpengikutnya melalui proses komunikasi dalam upaya mencapai tujuan organisasi. Kepemimpinan membutuhkan penggunaan kemampuan dan bakat seseorang secara aktif untuk mempengaruhi pihak lain dalam rangka usaha mencapai tujuan. Seorang pemimpin mengetahui sifat-sifat individual orang-orang kepercayaannya dan ia dapat mengetahui tindakan apa yang dapat merangsang mereka bekerja dengan sebaik-baiknya. Salah satu cara tersebut adalah sikap para pekerja terhadap pimpinannya, yang dapat ditunjukkan dari pola komunikasi antara karyawan dengan pemimpinnya. Pola komunikasi antara pemimpin dengan karyawan diharapkan membentuk suatu pola hubungan timbal balik yang harmonis sehingga komunikasi yang terjalin dapat memberikan kepuasan kerja dalam organisasi. Dengan demikian karyawan akan merasa bahwa dirinya telah diperlakukan secara baik, dari sisi moril maupun materil.

$$
\text { Dalam suatu perusahaan, }
$$

komunikasi terjadi dari interaksi antara individu-individu yaitu interaksi antara atasan dan bawahan. Komunikasi tersebut dapat terjadi secara horizontal (bawahan dengan bawahan) dan komunikasi secara vertikal (atasan dengan bawahan). Komunikasi yang berlangsung tersebut harus mudah dimengerti dan disampaikan dengan lengkap dan tepat sasaran oleh atasan maupun bawahan, dengan menggunakan komunikasi tertulis, komunikasi lisan, dan komunikasi non-verbal.

Selain kepemimpinan dan komunikasi, lingkungan kerja dalam suatu perusahaan juga merupakan faktor lain yang harus diperhatikan manajemen. Meskipun lingkungan kerja tidak melaksanakan proses produksi dalam suatu perusahaan, namun lingkungan kerja mempunyai pengaruh langsung terhadap para karyawan yang melaksanakan proses produksi tersebut. Lingkungan kerja yang memusatkan bagi karyawannya dapat meningkatkan produktivitas kerja. Sebaliknya lingkungan kerja yang tidak memadai akan dapat menurunkan produktivitas kerja dan akhirnya menurunkan motivasi kerja karyawan.

Suatu kondisi lingkungan kerja dikatakan baik atau sesuai apabila manusia dapat melaksanakan kegiatan secara optimal, sehat, aman dan nyaman. Kesesuaian lingkungan kerja dapat dilihat akibatnya dalam jangka waktu yang lama. Lebih jauh lagi lingkungan-lingkungan kerja yang kurang baik dapat menuntut tenaga kerja dan waktu yang lebih banyak dan tidak mendukung diperolehnya rancangan sistem kerja yang efisien. Menurut Nitisemito (2000) mendefinisikan lingkungan kerja adalah segala sesuatu yang ada di sekitar para pekerja yang dapat mempengaruhi dirinya dalam menjalankan tugas-tugas yang diembannya. Sedangkan menurut Sedarmayati (2001) mendefinisikan lingkungan kerja adalah keseluruhan alat perkakas dan bahan yang dihadapi, lingkungan sekitarnya dimana seseorang bekerja, metode kerjanya, serta pengaturan kerjanya baik sebagai perseorangan maupun sebagai kelompok.

Berdasarkan acuan referensi yang diuraikan diatas, peneliti mencoba 
mengaitkannya pada fenomena yang terjadi pada PT. BPJS Ketenagakerjaan Kantor Wilayah DKI Jakarta sebagai penyelenggaraan program jaminan sosial merupakan salah satu tanggung jawab dan kewajiban negara - untuk memberikan perlindungan sosial ekonomi kepada masyarakat. Sesuai dengan kondisi kemampuan keuangan Negara. Indonesia seperti halnya negara berkembang lainnya, mengembangkan programjaminan sosial berdasarkan funded social security, yaitu jaminan sosial yang didanai oleh peserta dan masih terbatas pada masyarakat pekerja di sektor formal. Sejarah terbentuknya PT Jamsostek (Persero) mengalami proses yang panjang, dimulai dari UU No.33/1947 jo UU No.2/1951 tentang kecelakaan kerja, Peraturan Menteri Perburuhan (PMP) No.48/1952 jo PMP No.8/1956 tentang pengaturan bantuan untuk usaha penyelenggaraan kesehatan buruh, PMP No.15/1957 tentang pembentukan Yayasan Sosial Buruh, PMP No.5/1964 tentangpembentukan Yayasan Dana Jaminan Sosial (YDJS), diberlakukannya UU No.14/1969 tentang Pokok-pokok Tenaga Kerja. Secara kronologis proses lahirnya asuransi sosial tenaga kerja semakin transparan.Manajemen sedang mengalami permasalahan mengenai komunikasi yang dirasa kurang efektif dan terkesan kurang sehat. Untuk itu masalah komunikasi yang menjadi masalah harus segera mungkin dicari jalan keluarnya, tidak bisa diidamkan begitu saja, karena pekerjaan akan berjalan lancar bila terjalin komunikasi yang baik antar karyawan dalam menjalankan pekerjaannya.

Tujuan dari penelitian adalah untuk mengetahui pengaruh kepemimpinan dan komunikasi terhadap kinerja karyawan PT. BPJS Ketenagakerjaan Kantor Wilayah DKI Jakarta.

\section{LANDASAN TEORI}

\section{Kepemimpinan}

Kepemimpinan

memainkan peranan yang dominan, krusial dan kritikal dalam keseluruhan upaya untuk meningkatkan kinerja, baik pada tingkat individual, pada tingkat kelompok, dan pada tingkat organisasi. Dikatakan demikian karena kinerja tidak hanya disoroti dari sudut pandang kinerja para tenaga pelaksana berbagai kegiatan operasional, yang pada umumnya bersifat teknis, akan tetapi juga dari kinerja kelompok kerja dan bahkan juga kinerja manajerial (Siagian, 2003). Peran yang dominan, krusial, dan kritikal tersebut terlihat dengan menyoroti definisi kepemimpinan, peranan dan fungsinya, pengenalan tipologinya, serta kemampuan menggunakan gaya kepemimpinan yang sifatnya situasional dengan memahami berbagai teori tentang kepemimpinan.

Tidak mudah memberikan definisi kepemimpinan yang sifatnya universal dan dapat diterima oleh semua pihak yang terlihat dalam kehidupan instansi. Bahkan ada yang mengatakan bahwa jenis-jenis definisi tersebut sama jumlahnya dengan jumlah para penulisnya. Akan tetapi terlepas dari cara atau gaya membuat definisi itu, "benang merah" yang terlihat ialah pengakuan tentang pentingnya kepemimpinan yang efektif dalam mengelola organisasi.

Kepemimpinan menurut: Subagyo (2000), Yang dimaksud dengan pemimpin adalah seseorang yang dengan cara apapun mampu mempengaruhi orang atau pihak lain untuk berbuat sesuatu sesuai dengan kehendak orang itu sendiri sehingga tujuan yang telah ditentukan tercapai. Sedangkan Scott dan Podsakoff (1982), Menilai kepemimpinan sebagai perilaku dari satu orang yang berbeda dengan perilaku orang lain. Mereka kemudian mengembangkan 
argumen yang meyakinkan untuk mendukung asas itu.

Peranan pimpinan dalam organisasi menurut Kast (2001) menyatakan bahwa, seseorang yang menduduki jabatan pemimpin atau manajerial dalam suatu organisasi memainkan peranan yang sangat penting. Peran tersebut meliputi peran sebagai berikut: 1). Peran yang bersifat interpersonal; Dalam menjalankan kepemimpinannya, seorang pimpinan berinteraksi dengan manusia, bukan hanya dengan bawahannya akan tetapi juga dengan berbagai pihak yang berkepentingan (stake holders) di dalam dan diluar organisasi. Kemampuan untuk berinteraksi dengan pihak-pihak tersebutlah yang disebut dengan kemampuan interpersonal. Kemampuan tersebut nampak dalam tiga bentuk yaitu: a). Selaku simbol keberadaan organisasi peranan tersebut dimainkan dalam berbagai kegiatan yang sifatnya legal dan seremonial, contohnya menghadiri berbagai upacara resmi, memenuhi undangan atasan, rekan setingkat, para bawahan dan mitra kerja.

b). Selaku pemimpin bertanggung jawab untuk memotivasi dan memberikan arahan kepada para bawahan yang dalam kenyataannya berarti "berurusan" dengan semua bawaan. c). Selaku penghubung, dimana seorang pemimpin harus menciptakan jaringan yang luas dengan memberi perhatian khusus kepada mereka yang mampu berbuat sesuatu bagi organisasi dan juga berbagai pihak yang memiliki informasi yang diperlukan oleh organisasi instansi. Peran tersebut dilakukan seperti pembicaraan per telepon, menggunakan e-mail, pertemuan, rapat, dan kunjungan kerja. 2). Peran yang bersifat informational; Peran tersebut nampak dalam tiga bentuk, yaitu: a). Peran pemantau arus informasi yang terjadi dari dan ke dalam organisasi. Seorang Manager selalu menerima berbagai informasi dari dalam dan dari luar yang berkaitan dengan organisasi instansi. b). Peran sebagai pembagi atau disseminator informasi. Berbagai informasi yang diterima seseorang mungkin berguna dalam penyelenggaraan fungsi manajerialnya akan tetapi mungkin pula untuk disalurkan kepada orang atau pihak lain dalam organisasi. Peran ini menuntut pemahaman informasi yang mendalam tentang makna informasi yang diterimanya, dan pengetahuan tentang berbagai fungsi yang harus diselenggarakan. c). Peran selaku juru bicara organisasi. Peran ini memerlukan kemampuan menyalurkan informasi secara tepat kepada berbagai pihak di luar organisasi, terutama jika menyangkut informasi tentang rencana, kebijaksanaan, tindakan dan hasil yang telah dicapai oleh organisasi. 3). Peran pengambil keputusan; Peran ini mengambil empat bentuk, yaitu: a). Selaku entrepreneur. Seorang pemimpin diharapkan mampu menguji secara terus menerus situasi yang dihadapi oleh organisasi, untuk mencari dan menemukan peluang yang dapat dimanfaatkan meskipun kajian itu menuntut terjadinya perubahan dalam organisasi. b). Peredam gangguan. Kesediaan memikul tanggung jawab untuk menanggung tindakan korektif apabila organisasi menghadapi gangguan serius yang apabila tidak ditangani akan berdampak negatif bagi organisasi instansi. c). Pembagi sumber dana dan daya. Peran ini sering dikaitkan dengan wewenang dan kekuasaan. Banyak orang berpendapat makin tinggi posisi kepemimpinan maka kekuasaan yang dimiliki menjadi semakin besar. Kewenangan itu antara lain: wewenang untuk mempromosikan seseorang, mengenakan sanksi termasuk mengalokasikan dana dan waktu. Kewenangan atau kekuasan itulah yang membuat para bawahan bergantung padanya. d). Perunding bagi organisasi. Telah dikemukakan bahwa makin tinggi jabatan seseorang, ia makin lebih banyak 
berinteraksi dengan berbagai pihak di luar organisasi ketimbang dengan orangorang dalam kata lain ia semakin sering berperan selaku perunding untuk organisasi.

Perilaku pemimpin yang berkaitan dengan kemampuan manajer atau pemimpin akan mempengaruhi bawahannya. Kemampuan dalam memimpin dan diikuti oleh bawahan dikenal dengan gaya kepemimpinan. Blanchard (1982) berpendapat bahwa gaya kepemimpinan seseorang adalah pola perilaku yang ditujukan ketika seseorang mencoba mempengaruhi orang lain. Pentingnya pengenalan berbagai tipe kepemimpinan terletak pada pemahaman ciri-cirinya secara tepat karena ciri-ciri tertentu dapat digunakan pada situasi dan kondisi tertentu dalam menjalankan roda organisasi. Jadi agar seorang pemimpin dapat meningkatkan efektivitas kepemimpinannya dengan kemampuan tinggi perlu menggunakan gaya yang situasional yang artinya gaya yang berbeda pada situasi dan kondisi yang berlainan.

Lippit (1998) dari berbagai studi tentang kepemimpinan diketahui ada lima tipe pemimpin yaitu: 1). Tipe Pemimpin Otoriter; Ciri-ciri yang menonjol pada tipe ini adalah: a). Penonjolan diri yang berlebihan sebagai simbol keberadaan organisasi, hingga cenderung bersikap bahwa dirinya dan organisasi adalah identik. b). Kegemaran menonjolkan diri sebagai "penguasa tunggal" dalam organisasi instansi. c). Dihinggapi penyakit megalomaniac dalam arti "gila hormat" dan menggemari berbagai seremoni yang menggambarkan kehebatannya. d). Tujuan pribadinya identik dengan tujuan instansi, dengan demikian timbul persepsi bahwa para karyawan merupakan hamba baginya. e). Karena pengabdian diinterpretasikan yang sifatnya pribadi, loyalitas para bawahan merupakan tuntutan yang sangat kuat. Demikian kuatnya hingga mengalahkan kriteria kekaryaan yang lain seperti kinerja, kejujuran, serta penerapan norma-norma moral dan etika. f). Menentukan dan menerapkan disiplin organisasi yang keras dan menjalankannya dengan sikap yang kaku. Tidak ada kesempatan bagi karyawan untuk bertanya, apalagi mengajukan saran atau pendapat. g). Pengawasan atau pengendalian sangat ketat. Hal ini terjadi karena pemimpin tipe ini menyadari bahwa gaya kepemimpinannya yang otoriter itu hanya efektif jika yang bersangkutan menerapkan pengendalian atau pengawasan yang ketat. 2). Tipe Pemimpin Paternalistik; Ciri-ciri pemimpin dengan gaya kepemimpinan tipe ini adalah: a). Penonjolan keberadaannya sebagai simbol organisasi. b). Sering menonjolkan sikap "paling mengetahui", karena itu dalam prakteknya tidak jarang menunjukkan gaya menggurui. c). Memperlakukan bawahan sebagai orang-orang yang belum dewasa bahkan seolah-olah mereka masih anak-anak. d). Bersifat melindungi, dalam hal ini mungkin beritikad baik, namun dalam prakteknya akan tercermin sikap manajemen yang tidak mendorong bawahan untuk mengambil resiko. e). Sentralisasi pengambilan keputusan, artinya pemimpin yang jadi pusat pengambilan keputusan. $\quad \mathrm{f})$. Melakukan pengawasan yang ketat. Dari ciri-ciri diatas, dapat ditarik kesimpulan bahwa tipe ini bukan tipe yang ideal karena meskipun pemimpin beritikad baik, namun hal tersebut sering menjelma menjadi suatu bentuk pemasangan. 3). Tipe Laizez Faire; Ciri-ciri yang menonjol adalah: a). Gaya santai yang berangkat dari pandangan bahwa organisasi tidak menghadapi masalah yang serius dan kalaupun ada, selalu dapat ditemukan penyelesaiannya. b). Tidak senang mengambil resiko. c). Gemar melimpahkan wewenang pada bawahan. d). Enggan mengenakan sanksi, 
apalagi yang keras terhadap bawahan yang menampilkan perilaku disfungsional atau menyimpang. e). Memperlakukan bawahan sebagai rekan. f). Keserasian dalam interaksi organisasional dipandang sebagai etos yang perlu dipertahankan. Tipe ini bukanlah merupakan tipe pemimpin yang ideal, karena sulit sekali ditemukan adanya organisasi instansi yang dihadapkan dimana situasi ini tepat. 4). Tipe Demokratik; Ciri-ciri pemimpin dengan gaya kepemimpinan tipe ini adalah: a). Mengakui harkat dan martabat manusia, dengan demikian selalu memperlakukan karyawan dengan cara yang manusiawi. b). Menerima pendapat bahwa SDM merupakan unsur yang paling strategis dalam organisasi meskipun sumberdaya dan dana lainnya merupakan sumber yang penting. c). Bawahan adalah insan dengan jati diri yang khas, karena itu diperlakukan dengan mempertimbangkan kekhasannya. d). Tangguh membaca situasi dan dapat menyesuaikan gaya kepemimpinan dengan situasi tersebut. e). Rela dan mau melimpahkan wewenang pengambilan keputusan kepada para bawahannya. f). Mendorong bawahan untuk mengembangkan kreativitasnya. g). Tidak ragu-ragu membiarkan bawahan mengambil keputusan, dengan catatan faktor-faktor yang mempengaruhi telah diperhitungkan dengan matang. h). Bersifat mendidik dan membina bawahannya. Banyak orang yang mengatakan bahwa tipe demokratik adalah tipe yang didambakan. Hanya saja tetap tidak boleh dilupakan bahwa tipe inipun tidak bisa diterapkan secara konsisten dan terus menerus. Terlepas dari situasi organisasi. 5). Tipe Pemimpin Otoriter; Ciri-ciri pemimpin dengan gaya kepemimpinan tipe ini adalah: a). Percaya diri yang besar. b). Mempunyai visi kedepan yang jelas. c). Kemampuan mengaktualisasikan visi. d). Keyakinan yang kuat tentang kuatnya visi yang dinyatakan kepada para bawahan. e). Berani membuat komitmen, mengambil resiko, mempertaruhkan reputasi, membayar biaya tinggi, memberikan pengorbanan yang diperlukan demi tercapainya visi yang telah ditetapkan. f). Memiliki pemahaman yang mendalam dan tepat tentang sifat lingkungan yang dihadapi.

Kepemimpinan, merupakan hal yang sangat dominan didalam manajemen, karena kepemimpinan maka proses manajemen akan berjalan dengan baik dan karyawan akan bergairah dalam melakukan tugasnya. Baik dan tidaknya suatu instansi sangatlah tergantung daripada kecakapan dan kemampuan manajer dalam melaksanakan kepemimpinan untuk mengarahkan bawahannya. Demikian pula halnya keberhasilan ataupun kegagalan suatu organisasi terutama di lembaga-lembaga pemerintah sangat bergantung pada gaya kepemimpinan para pemimpin organisasi tersebut. Gaya kepemimpinan merupakan norma perilaku yang digunakan oleh pimpinan pada saat mencoba mempengaruhi bawahannya.

Menurut Rusman (1998), seorang pemimpin yang berhasil (sukses), sekurang-kurangnya memiliki ciri-ciri berikut: 1). Menyadari dan memahami tujuan organisasi. 2). Memahami gaya, watak, dan sifat dirinya sendiri dan bagaimana dampak keluarnya. 3). Cakap mendiagnosa situasi, kondisi dan lingkungan serta mengetahui keperluan karyawan bawahannya. 4). Mampu menyesuaikan gaya dan situasi kondisi dan lingkungan untuk kemudian dibawa kearah mencapai tujuan. 5). Mampu dan cakap berkomunikasi.

Sementara itu. Sherman dalam Sumawijaya (1997) mengemukakan bahwa untuk mengetahui seorang pemimpin dengan baik atau tidak dapat dilihat dari: 1). Kemampuan menjalankan sistem kerja. 2). Kemampuan meningkatkan kemampuan dirinya dan 
bawahannya.3). Kemampuan memotivasi dan memobilisasi.

\section{Komunikasi}

Komunikasi adalah pertukaran pesan verbal maupun non verbal antara si pengirim dengan si penerima pesan untuk mengubah tingkah laku (Muhammad, 2004). Dengan adanya komunikasi maka akan memungkinkan seseorang untuk mengkoordinasikan suatu kegiatan kepada orang lain untuk mencapai tujuan bersama. Namun demikian, komunikasi bukan hanya sekedar transfer makna, melainkan mengandung suatu proses transaksional, yaitu berkaitan erat dimana orang berkomunikasi dengan pihak lainnya dalam upaya membentuk suatu makna serta mengembangkan harapanharapannya (Ruslan, 2002).

Berdasarkan uraian di atas maka dapat dijelaskan setiap inti dari pernyataan di atas yaitu: 1). Mempertukarkan simbol, artinya bahwa dalam sebuah proses komunikasi, akan terjadi pertukaran simbol antara komunikator dengan komunikan. Simbol tersebut memiliki pengertian yang sama dan dapat disampaikan secara lisan maupun tulisan. 2). Membentuk makna tertentu, artinya bahwa komunikasi itu bersifat transaksional, dimana orang akan saling belajar satu sama lain, tugas pengalaman atau pengetahuan melalui simbol-simbol yang sama-sama dimengerti dan membentuk suatu makna tertentu yang dapat dipahami oleh kedua belah pihak. Semakin sering orang berkomunikasi maka akan semakin banyak memiliki makna yang sama. Semakin banyak berkomunikasi dalam sebuah organisasi maka akan semakin besar pula kemungkinan untuk mengembangkan suatu kesepakatan (consensus) dan hingga mampu menciptakan opini dan persepsi. 3). mengembangkan harapan-harapan, yaitu mempelajari simbol-simbol tersebut dan kemudian menghubungkan dengan pengalaman yang diperoleh serta mengamati dan menganalisis apa yang dilakukan oleh pihak lain ketika menggunakan simbol-simbol tersebut.

Dalam praktek berkomunikasi biasanya seseorang akan menemui berbagai macam hambatan yang jika tidak dapat ditanggapi dan disikapi secara tepat akan membuat proses komunikasi yang terjadi menjadi sia-sia karena pesan tidak tersampaikan atau yang sering terjadi adalah terjadinya penyimpangan. Adapun hal-hal yang sering terjadi adalah karena ketidakmampuan seorang penyampai pesan, hambatan dalam komunikasi Widjaja (1996) diantaranya adalah: 1). Hambatan yang bersifat teknis yaitu pesan dapat tidak utuh diterima komunikan karena gangguan teknis misalnya, suara tidak sampai karena pengeras suara rusak, kebisingan, lalu lintas dan sebagainya. 2). Hambatan bahasa yaitu pesan akan salah ditafsirkan sehingga tidak mencapai apa yang dinginkan. Jika bahasa yang kita gunakan tidak dipahami oleh komunikan yang mungkin dapat diartikan berbeda. 3). Hambatan bola salju yaitu pesan menjadi membesar sampai jauh yakni pesan ditanggapi sesuai dengan selera komunikan-komunikator akibatnya semakin jauh menyimpang dari pesan semula, hal ini timbul karena: a). Daya mampu manusia menerima dan menghayati pesan terbatas. b). Pengaruh kepribadian dari yang bersangkutan. c). Sebenarnya setiap macam, bentuk komunikasi mempunyai hambatan masing-masing.

Adanya komunikasi merupakan basis untuk melakukan kerja sama, interaksi dan mempunyai pengaruh di dalam manajemen organisasi (Ruslan, 2002), misalnya dalam hal: 1). Pengambilan keputusan berdasarkan informasi yang diterima dan akurat serta jelas sumber - sumbernya. 2). Menempatkan posisi atau lokasi pengambil keputusan, misalnya top 
management atau middle management. 3). Menetapkan sasaran dan tujuan, yaitu perlunya kesatuan pendapat atau konsensus bersama bagi pihak-pihak yang terlibat, baik individual maupun dengan pencapaian sasaran dan tujuan utama organisasi.

$$
\text { Bentuk-bentuk komunikasi; }
$$

Jaringan komunikasi dalam suatu organisasi yaitu pesan, instruksi, dan informasi disampaikan secara resmi, yang artinya ditentukan oleh jenjang hirarki resmi organisasi-dari atasan ke bawahan atau sebaliknya dan untuk melaksanakan fungsi pekerjaannya maka jaringan komunikasi tersebut dinamakan jaringan komunikasi formal. Didalam komunikasi organisasi maka terdapat dua bentuk komunikasi yaitu: 1). Komunikasi Verbal; Komunikasi verbal yaitu komunikasi yang menggunakan simbol atau kata-kata, baik yang dinyatakan secara oral maupun tulisan (Muhammad, 2004). 2). Komunikasi Non Verbal; Komunikasi non verbal adalah penciptaan atau pertukaran pesan dengan tidak menggunakan kata-kata, seperti menggunakan gerakan badan, sikap tubuh, kontak mata, vokal yang buka berupa kata-kata, ekspresi muka, sentuhan dan kedekatan (Muhammad, 2004).

Selain itu jaringan komunikasi dapat dibedakan menjadi dua yaitu komunikasi formal dan informal. Bila pesan mengalir melalui jalan resmi atau formal yang ditentukan oleh hirarki resmi organisasi atau oleh fungsi pekerjaan maka pesan tersebut menurut jaringan formal. Sebaliknya jika pesan mengalir tidak melalui jalan resmi atau formal yang ditentukan oleh hirarki resmi organisasi atau oleh fungsi pekerjaan maka pesan tersebut menurut jaringan informal.

\section{Kinerja Karyawan}

Kinerja dalam bahasa Indonesia sebenarnya terjemahan secara bebas dari kata "performance". Kinerja dalam arti yang agak terbatas sering digunakan untuk mengukur pencapaian kerja seseorang seperti tugas yang diberikan kepada seseorang dalam organisasi. Berbagai pendapat mengenal pengertian kinerja tersebut antara lain adalah sebagai berikut: Timpe yang diterjemahkan oleh Cikmat (2000) mengemukakan bahwa: "kinerja adalah kulminasi tiga elemen yang saling berkaitan: Keterampilan, upaya kerja dan sifat keadaan-keadaan eksternal". Werther and Davis, yang dikutip oleh Zainun (2001) berpendapat bahwa "penilaian kinerja adalah suatu proses penilaian atas kinerja suatu organisasi termasuk penilaian prestasi karyawan". Porter and Lawler yang diterjemahkan oleh As'ad (2009) mengemukakan bahwa "Kinerja adalah yang diperoleh seseorang dari perbuatannya".

Penilaian kinerja karyawan terdiri dari tiga langkah: 1). Mendefinisikan pekerjaan; Mendefinisikan pekerjaan berarti memastikan bahwa anda dan bawahan anda sepakat tentang tugastugasnya dan standar jabatan. 2). Menilai Kinerja; Menilai kinerja berarti membandingkan kinerja aktual bawahan anda dengan standar-standar yang ditetapkan. 3). Memberi umpan balik; Umpan balik disini kinerja dan kemajuan bawahan dibahas dan rencana-rencana dibuat untuk perkembangan apa saja yang dituntut.

Minner (1998) menjelaskan dimensi-dimensi yang mempengaruhi kinerja, ada empat: 1). Quality of Work (Kualitas hasil), menyangkut kesalahan, pemborosan waktu, dan ketepatan dan sebagainya. 2). Quality of Work (Kuantitas hasil), menyangkut jumlah produksi yang dihasilkan. 3). Time at Work (Waktu kerja), tingkat ketidakhadiran karyawan, keterlambatan, pemborosan waktu, kesinambungan kerja dan lain-lain. 4). Cooperation with Others (Kerjasama 
dengan pihak lain), menyangkut bagaimana seseorang membantu atau menghambat orang lain menyelesaikan pekerjaannya.

\section{METODE PENELITIAN}

Penelitian ini membahas tentang kinerja karyawan pada PT. BPJS Ketenagakerjaan Kantor Wilayah DKI Jakarta, maka metode penelitian yang digunakan adalah metode kuantitatif deskriptif menggunakan sistem survey.

Populasi dalam penelitian ini adalah karyawan pada PT. BPJS Ketenagakerjaan Kantor Wilayah DKI Jakarta, yang berjumlah 30 orang karyawan. Peneliti mengambil dan menggunakan semua sampel yang ada untuk diteliti dikarenakan minimnya populasi yang ada di PT. BPJS Ketenagakerjaan Kantor Wilayah DKI Jakarta.

Sebelum melakukan analisis data yang menggunakan metode regresi linear sederhana dan berganda, terlebih dahulu dilakukan uji validitas dan reliabilitas instrumen-instrumen penelitian, hal ini dilakukan untuk memastikan bahwa data yang dipakai adalah data yang baik.

\section{HASIL PENELITIAN DAN PEMBAHASAN}

\section{Uji Instrumen Data}

Berdasarkan uraian tersebut di atas, maka untuk dapat menentukan apakah variabel kepemimpinan dan komunikasi dapat dijadikan pengukur terhadap kinerja karyawan PT. BPJS Ketenagakerjaan Kantor Wilayah DKI Jakarta. Namun sebelumnya data diolah terlebih dahulu dan dilakukan pengujian terhadap varibel yang digunakan yaitu kepemimpinan, komunikasi dan kinerja untuk mengetahui apakah data tersebut akurat dan dapat dipercaya.

\section{Uji Validitas}

Pengujian validitas ini dilakukan untuk menguji apakah tiap butir pernyataan telah mewakili indikator yang akan diteliti, persyaratan minimum untuk dapat dikatakan valid adalah $\mathrm{r}=$ 0,30 . Jadi, apabila korelasi antara butirbutir item pernyataan dengan skor total kurang dari 0,30, maka butiran dalam instrumen tersebut dapat dikatakan tidak valid. Uji validitas dilakukan dengan melihat korelasi antara skor masingmasing item pernyataan dengan skor total.

\section{Uji Validitas Instrumen Variabel}

Dari perhitungan koefisien korelasi skor tiap butir pernyataan instrument dari 30 responden tentang kepemimpinan dengan jumlah 10 pernyataan; instrumen komunikasi 10 pernyataan dan instrumen kinerja karyawan 10 pernyataan dengan total skor setiap responden diperoleh bahwa dari semua butir pernyataan variabel kepemimpinan, komunikasi dan kinerja karyawan hasilnya adalah valid.

\section{Uji Reliabilitas}

Pengujian reliabilitas ini dilakukan untuk menguji seberapa jauh hasil pengukuran yang dapat diandalkan secara konsisten. Pada tabel hasil pengujian reliabilitas berikut, diketahui bahwa semua variabel mempunyai alpha di atas 0,6 yang berarti bahwa semua variabel dalam penelitian ini dapat diandalkan. 
Tabel 1: Hasil Uji Reliabilitas Variabel

\begin{tabular}{lcc}
\hline \multicolumn{1}{c}{ Variabel } & Cronbach's Alpha & Keterangan \\
\hline Kepemimpinan & 0.979 & Reliabel \\
Komunikasi & 0.976 & Reliabel \\
Kinerja Karyawan & 0.976 & Reliabel \\
\hline
\end{tabular}

Sumber: Hasil pengolahan data, 2017

Berdasarkan

angka-angka

reliabilitas cronbach alpha tersebut tampak bahwa seluruh pernyataan yang ada membentuk ukuran yang reliabel kepemimpinan, komunikasi, dan kinerja karyawan membentuk ukuran yang reliabel dari masing-masing variabel.

\section{Analisis Hasil Penelitian}

Tabel 2: Pengaruh Kepemimpinan dan Komunikasi Terhadap Kinerja Karyawan

\begin{tabular}{lccccc}
\hline \multirow{2}{*}{ Variabel } & $\mathbf{R}^{\mathbf{2}}$ & Konstanta & $\begin{array}{c}\text { Koefisien } \\
\text { Regresi }\end{array}$ & Sig. & $\boldsymbol{\alpha}$ \\
\cline { 2 - 6 } & 0,982 & 1,692 & 0,780 & 0,000 & 0,05 \\
\hline $\begin{array}{l}\text { Kepemimpinan } \\
\text { Komunikasi }\end{array}$ & 0,270 & 0,000 & 0,05 \\
\hline Pengujian Signifikan & & & & \\
\hline F hitung > F tabel = 71,431 > 3,168 \\
\hline $\begin{array}{l}\text { Keterangan: Variabel Kinerja Karyawan } \\
\text { Sumber : data diolah 2019 }\end{array}$
\end{tabular}

Pada Tabel 2, nilai $\mathrm{F}$ hitung sebesar 71,431 jika dibadingkan dengan $F$ tabel sebesar 3,34, maka F hitung lebih besar dari $\mathrm{F}$ tabel $(71,431>3,34)$, artinya secara bersama-sama terdapat pengaruh secara signifikan kepemimpinan dan komunikasi terhadap kinerja karyawan pada PT. BPJS Ketenagakerjaan Kantor Wilayah DKI Jakarta. Nilai koefisien determinasi $\left(\mathrm{R}^{2}\right)$ sebesar 0.982 , hal ini menunjukkan kepemimpinan dan komunikasi dapat memberikan sumbangan terhadap kinerja karyawan sebesar $98.2 \%$, dan sisanya $1.8 \%$ dipengaruhi oleh variabel lain yang tidak dijelaskan pada penelitian ini.

Persamaan Regresi $\mathrm{Y}=1,692+0,780$ $\left(\mathrm{X}_{1}\right)+0,270\left(\mathrm{X}_{2}\right)$
Koefisien regresi kepemimpinan bertanda positif menunjukkan adanya hubungan yang positif kepemimpinan yang menyebabkan kenaikan sebesar 0.780 terhadap kinerja karyawan. Hal ini menunjukkan dengan adanya keberhasilan dalam penerapan model kepemimpinan pada PT. BPJS Ketenagakerjaan Kantor Wilayah DKI Jakarta maka kinerja karyawan dapat meningkat. Koefisien regresi komunikasi bertanda positif menunjukkan adanya hubungan positif komunikasi yang menyebabkan kenaikan sebesar 0.270 terhadap kinerja karyawan. Hal ini menunjukkan dengan adanya komunikasi yang baik dari para pimpinan PT. BPJS Ketenagakerjaan Kantor Wilayah DKI Jakarta dapat meningkatkan kinerja karyawan. 
Tabel 3: Pengaruh Kepemimpinan Terhadap Kinerja Karyawan

\begin{tabular}{lccccc}
\hline \multirow{2}{*}{ Variabel } & $\mathbf{R}^{\mathbf{2}}$ & Konstanta & $\begin{array}{c}\text { Koefisien } \\
\text { Regresi }\end{array}$ & Sig & $\boldsymbol{\alpha}$ \\
\cline { 2 - 6 } & 0.981 & 1,165 & 1,020 & 0,000 & 0.05 \\
\hline Kepemimpinan & \multicolumn{7}{c}{ Parameter } \\
\hline Pengujian Signifikan & & & & \\
\hline t hitung > t tabel = 38,446 > 1,701 & & & \\
\hline Keterangan: Variabel Kinerja Karyawan \\
Sumber : data diolah 2019
\end{tabular}

Berdasarkan Tabel 3, nilai koefisien determinasi $\left(\mathrm{R}^{2}\right)$ sebesar 0.981, hal ini menunjukkan kepemimpinan dapat memberikan sumbangan sebesar $98.1 \%$ kepada kinerja karyawan, sisanya sebesar $1,9 \%$ disumbangkan oleh faktor lain yang tidak dijelaskan.

Persamaan Regresi $\mathrm{Y}=1,165+1,020$ $\left(\mathrm{X}_{1}\right)$

Koefisien regresi kepemimpinan bertanda positif menunjukkan adanya hubungan positif kepemimpinan yang menyebabkan kenaikan sebesar 1.020 terhadap kinerja karyawan. Hal ini menunjukkan dengan keberhasilan penerapan model kepemimpinan pada PT. BPJS Ketenagakerjaan Kantor Wilayah DKI Jakarta maka kinerja karyawan akan semakin meningkat. Untuk menguji hubungan kepemimpinan terhadap kinerja karyawan signifikan atau tidak, dilakukan pengujian $t$ hitung dibandingkan dengan $\mathrm{t}$ tabel dengan tingkat $\alpha=0,05$, hasilnya adalah $\mathrm{t}$ tabel $=1.701$ yang dilihat dari tabel distribusi $\mathrm{t}$ (derajat kebebasan $=\mathrm{n}-2$ dengan uji dua pihak). Berdasarkan perhitungan tersebut di atas dapat dinyatakan bahwa Nilai $\mathrm{t}$ hitung $=$ 38.446 dan $\mathrm{t}$ tabel $=1.701$ atau $\mathrm{t}$ hitung $>\mathrm{t}$ tabel $(38.446>1.701)$, maka dapat diartikan terdapat pengaruh yang signifikan kepemimpinan terhadap kinerja karyawan pada PT. BPJS Ketenagakerjaan Kantor Wilayah DKI Jakarta.

Tabel 4: Pengaruh Komunikasi Terhadap Kinerja Karyawan

\begin{tabular}{|c|c|c|c|c|c|}
\hline \multirow[b]{2}{*}{ Variabel } & \multicolumn{5}{|c|}{ Parameter } \\
\hline & $\mathbf{R}^{2}$ & Konstanta & $\begin{array}{c}\text { Koefisien } \\
\text { Regresi }\end{array}$ & Sig & $\alpha$ \\
\hline Komunikasi & 0,973 & 2,048 & 1,131 & 0,000 & 0.05 \\
\hline \multicolumn{6}{|c|}{ Pengujian Signifikan } \\
\hline \multicolumn{6}{|c|}{$\mathrm{t}$ hitung $>\mathrm{t}$ tabel $=9,306>2,004$} \\
\hline
\end{tabular}

Berdasarkan Tabel 4, nilai koefisien determinasi $\left(\mathrm{R}^{2}\right)$ sebesar 0.973, hal ini menunjukkan komunikasi dapat memberikan sumbangan sebesar 97.3\% kepada kinerja karyawan, sisanya sebesar $2.7 \%$ disumbangkan oleh faktor lain yang tidak dijelaskan.
Persamaan Regresi $\mathrm{Y}=2,048+1,131$ $\left(\mathrm{X}_{2}\right)$

Koefisien regresi komunikasi bertanda positif menunjukkan adanya hubungan positif komunikasi yang menyebabkan kenaikkan sebesar 1.131 
terhadap kinerja karyawan. Hal ini menunjukkan dengan adanya komunikasi yang baik pada PT. BPJS Ketenagakerjaan Kantor Wilayah DKI Jakarta akan meningkatkan kinerja karyawan. Untuk menguji hubungan komunikasi terhadap kinerja karyawan signifikan atau tidak, dilakukan pengujian t hitung dibandingkan dengan t tabel dengan tingkat kepercayaan $(\mathrm{a})=$ 0.05 , hasilnya adalah $\mathrm{t}$ tabel $=1.701$ yang dilihat dari tabel distribusi $t$ (derajat kebebasan $=n-2$ dengan uji dua pihak). Berdasarkan perhitungan tersebut di atas dapat dinyatakan bahwa nilai $\mathrm{t}$ hitung $=31.512$ dibandingkan dengan $\mathrm{t}$ tabel 1.701 atau thitung $>\mathrm{t}$ tabel (31.512>1.701), maka dapat diartikan terdapat pengaruh yang signifikan komunikasi terhadap kinerja karyawan pada PT. BPJS Ketenagakerjaan Kantor Wilayah DKI Jakarta.

\section{Pembahasan}

\section{Pengaruh Kepemimpinan dan Komunikasi Terhadap Kinerja Karyawan PT BPJS Ketenagakerjaan Kantor Wilayah DKI Jakarta}

Berdasarkan hasil analisis

diketahui bahwa kepemimpinan dan komunikasi mendukung peningkatan kinerja karyawan PT. BPJS Ketenagakerjaan Kantor Wilayah DKI Jakarta, berarti makin baik upaya perusahaan dalam memperhatikan penerapan model kepemimpinan dan komunikasi yang diciptakan maka makin baik kinerja karyawan. Hasil penelitian ini sama dengan hasil penelitian yang dilakukan Utami dan Nugrahaningsih, (2017)., Rusdi, (2017), yang menyatakan bahwa kepemimpinan dan komunikasi berpengaruh positif dan signifikan terhadap kinerja karyawan. Dengan demikian hipotesis pertama dapat diterima.
Pengaruh Kepemimpinan Terhadap Kinerja Karyawan PT BPJS Ketenagakerjaan Kantor Wilayah DKI Jakarta

Dari hasil penelitian menunjukan bahwa adanya peningkatan kepemimpinan akan mendorong meningkatkan kinerja karyawan PT. BPJS Ketenagakerjaan Kantor Wilayah DKI Jakarta, berarti bahwa makin tinggi keberhasilan penerapan model kepemimpinan maka makin baik kinerja individu karyawan. Hasil penelitian ini sejalan dengan hasil penelitian yang dilakukan Muizu, (2014) dan Ritonga dan Tarigan, (2015) yang menyatakan bahwa kepemimpinan berpengaruh signifikan terhadap kinerja karyawan. Dengan demikian hipotesis kedua dapat diterima.

\section{Pengaruh Komunikasi Terhadap Kinerja Karyawan PT BPJS Ketenagakerjaan Kantor Wilayah DKI Jakarta}

Dari hasil penelitian menyatakan bahwa adanya peningkatan komunikasi akan mendorong meningkatkan kinerja karyawan PT. BPJS Ketenagakerjaan Kantor Wilayah DKI Jakarta, berarti bahwa makin baik komunikasi yang diciptakan dalam bekerja maka makin baik kinerja karyawan. Hasil penelitian ini sejalan dengan hasil penelitian yang dilakukan Wandi \& Adha, (2019) dan Rialmi dan Morsen, (2020) yang menyatakan bahwa komunikasi berpengaruh signifikan terhadap kinerja karyawan. Dengan demikian hipotesis ketiga dapat diterima.

\section{KESIMPULAN DAN SARAN}

\section{Kesimpulan}

Melalui hasil analisa dan pembahasan penelitian tentang kepemimpinan dan komunikasi dikaitkan dengan kinerja karyawan pada PT. BPJS Ketenagakerjaan Kantor 
Wilayah DKI Jakarta, diperoleh beberapa kesimpulan yang dapat menjawab pertanyaan di atas. Kesimpulan itu adalah sebagai berikut: 1). Secara bersama-sama kepemimpinan dan komunikasi sangat berpengaruh terhadap kinerja karyawan pada PT. BPJS Ketenagakerjaan Kantor Wilayah DKI Jakarta, berarti makin baik upaya perusahaan dalam memperhatikan penerapan model kepemimpinan dan komunikasi yang diciptakan maka makin baik kinerja karyawan. 2). Bahwa kepemimpinan berpengaruh terhadap kinerja karyawan pada PT. BPJS Ketenagakerjaan Kantor Wilayah DKI Jakarta. Hal ini berarti bahwa makin tinggi keberhasilan penerapan model kepemimpinan maka makin baik kinerja individu karyawan. 3). Hasil penelitian menunjukkan bahwa komunikasi berpengaruh terhadap kinerja karyawan pada PT. BPJS Ketenagakerjaan Kantor Wilayah DKI Jakarta. Hal ini berarti bahwa makin baik komunikasi yang diciptakan dalam bekerja maka makin baik kinerja karyawan.

\section{Saran}

Pada kesempatan ini peneliti mencoba untuk memberikan saran yang sekiranya dapat dijadikan rekomendasi khususnya bagi manajemen PT. BPJS Ketenagakerjaan Kantor Wilayah DKI Jakarta, yang dijadikan objek penelitian, maupun perusahaan sejenis dalam mengambil kebijakan-kebijakan untuk peningkatan kinerja karyawannya: 1). Dari hasil yang diperoleh, maka sebagai masukan yang disampaikan perusahaan perlu mempertahankan kondisi yang ada sekarang dan meningkatkan kondisi kearah yang lebih baik lagi. Dimana pimpinan harus lebih memperhatikan kebijakan yang sesuai dengan prosedur, meningkatkan kontrol kearah yang lebih baik terhadap karyawan, dan memberikan kewenangan kepada bawahannya untuk mengambil keputusan secara bersama. 2). Dengan diketahui bahwa variabel komunikasi ke atas dan komunikasi ke bawah memiliki pengaruh secara simultan terhadap kinerja karyawan maka perusahaan diharapkan bisa menjadikan hasil penelitian ini sebagai salah satu acuan perusahaan dalam melakukan keputusan terkait masalah kinerja karyawan.

\section{DAFTAR PUSTAKA}

\section{Amstrong, M. A Handbook of Human} Resource Management. Terjemahan oleh Sofyan Cikmat. 1999. PT Gramedia. Jakarta. 1996

As'ad, Mohammad. 2009. Seri Ilmu Sumber Daya Manusia: Psikologi Industri, Edisi IV. Yogyakarta: Liberty.

Hersey, P., \& Blanchard, K., 1982. Manajemen Perilaku Organisasi: Pendayagunaan Sumber Daya Manusia /4th eds., Ed: Agus Dharma. Jakarta: Erlangga.

Kast, Fremont E, James E, Rosenzweig. 2002. Organisasi dan Manajemen. penterjemah A. Hasim Ali. Jakarta: Bumi Aksara.

Lippitt, G.L.1998. "Improving Decision making with Groups." Dalam Group Development Selected Reading Series One National Training Laboratories. Washington, D.C.: Nat. Educ. Assoc.

Miner, John. 1998. Organizational Behavior, Performance and Productivity. Random House Business Division. New York.

Mufid, Muhammad. 2004. Komunikasi dan Regulasi Penyiaran. Jakarta: Erlangga.

Muizu, Wa Ode Zusnita. 2014. Pengaruh Kepemimpinan Terhadap Kinerja Karyawan. Pekbis Hurnal, Vol 6, No. 1, Maret 2014: 1-13. 
Nitisemito. Alex S. 2000. Manajemen Personalia: Manajemen Sumber Daya Manusia Ed. 3. Jakarta: Ghalia Indonesia.

Rialmi, Zackharia dan Morsen. 2020. Pengaruh Komunikasi Terhadap Kinerja Karyawan PT. Utama Metal Abadi. Jurnal Ilmiah Manajemen Sumber Daya Manusia. Vol. 3 No. 2 (2020). EISSN: 2598-9502; p-ISSN: 25812769.

Rivai, Veithzal. 2004. Manajemen Sumber Daya Manusia Untuk Perusahaan : Dari Teori Ke Praktik. Jakaarta: PT. Raja Grafindo Persada.

Ritongan, Tri Eva Juniangsih dan Tarigan, Usman. 2015. Pengaruh Kepemimpinan Terhadap Kinerja Pegawai Pada Kantor Sub. Dolog Wil. IV Padangsidempuan. Jurnal Administrasi Publik. Vol. 5, No. 1 (2015). ISSN: 2088-527X(print); ISSN: 2548-7787 (online).

Rusdi. 2017. Pengaruh Kepemimpinan dan Komunikasi Terhadap Kinerja Pegawai Pada Kantor Kecamatan Bacukiki Barat Kota Pare-Pare. Jurnal Noken: Ilmu-Ilmu Sosial. Universitas Muhammadiyah Sorong. Vol. 3 No. 1 (2017). PISSN: 2477-6203; e-ISSN: 26144336.

Ruslan, Rosady. 2002. Manajemen Humas dan Manajemen Komunikasi, Edisi Revisi. Jakarta: PT. Raja Grafindo Persada.

Rusman Hakim., 1998. Kiat Sukses Berwirausaha. Jakarta: PT Alex Media Komputindo.

Sastrodiningrat, Soebagio, 2000, Kapita Selekta, Manajemen \& Kepemimpinan. Jakarta: Ind-HillCo.

Scott, M. L.,J. M. G. Neshin and R. Young, 1982. Nutrition of Chicken 3th Ed. Publ. By M. L. Scott Association, New York.

Siagian, Sondang P, 2003. Teori dan Praktek Kepemimpinan. Jakarta: PT Rineka Cipta.

Sugiyono. 2003. Metode Penelitian Bisnis. Cetakan Kelima. Bandung: Penerbit CV. Alfabeta.

Timpe, D. 1992. Seri Ilmu dan Seri Manajemen Bisisnis Kreatifitas. Jakarta Indonesia: PT. Elek Media Komputindo.

Utami, Indah Wahyu dan Nugrahaningsih, Widi. 2017. Pengaruh Kepemimpinan dan Komunikasi Terhadap Kinerja Pegawai Kantor Kecamatan Gatak. Jurnal GEMA, THN XXX/52/Agustus 2016-2017. Hal. 2509-2516. ISSN:0215-3092.

Wandi, Didi dan Adha, Suhroji. 2019. Pengaruh Komunikasi Terhadap Kinerja Pegawai Pada Badan Penanggulangan Bencana Daerah (BPBD) Provinsi Banten. Jurnal Ekonomi Vokasi, Vol. 2 No. 2 Juli 2019. ISSN: 2622-4240. Hal. 1830.

Werther, William B. Jr dan Keith Davis, 1996, Human Resources Management, 5th Edition, New Jersey: McGraw-Hill, Inc.

Widjaja, H.A.W. 1988. Kelembagaan dan Organisasi. Jakarta: PT. Bumi Aksara.

Zainun, Buchari. 2000. Manajemen dan Motivasi. Jakarta: Balai Aksara 
